\title{
SEEKING POETIC JUSTICE: A READING OF DYLAN VOLLER'S PRISON GRAFFITI
}

When Four Corners aired the programme 'Australia's Shame', we entered into the prison cells of Darwin's Don Dale Youth Detention Centre and witnessed, through CCTV footage, the torture of mostly Aboriginal inmates, enduring a colonial system of controlling and 'settling' them down. Images of Dylan Voller under a spit-hood and strapped to a restraint chair are horridly similar to the prison machine in Kafka's 1914 story, In the Penal Colony. In his story, Kafka's prison machine is a 'bed' where the 'condemned man is laid face-down naked'1 and a marker carves script into the prisoner's back that is "not easy to decipher with one's eyes", but the prisoner can "decipher the words" "with his wounds."2 One purpose of literary studies is to decipher the cultural markers responsible for humanity's 'wounds' through the study of words or scripts known as texts. Kafka encourages us to read only the texts that wound us; books that allow us to reflect deeply and with feeling, in order to inspire positive changes to the material world. ${ }^{3}$ Recent texts that further expose Australia's racist penal system and invite critical and creative reflection include Kim Scott's Taboo, ${ }^{4}$ Paul Collis' Dancing Home, ${ }^{5}$ and selected stories from Tony Birch's Common People. ${ }^{6}$ These texts were published not long after the Four Corners' exposé, and also inform writing about the treatment of Aboriginal people by white police and prison guards.

The scope of this article seeks to provide a literary analysis of prison-themed writing by Australian Aboriginal author, Tony Birch, a creative writer as well as an academic who interviewed police involved in the death of Aboriginal boy Thomas ‘TJ' Hickey. Birch's characters resist police control and carry out rebellious tactical manoeuvres while in custody, such as graffiti-ing on prison walls and defacing police property in an effort to be seen in an invisible space. Birch's writing points to the possibilities of reflecting deeply on texts about prisons, but moreover, his work shows how graffiti from within prisons may represent a certain form of text that 'wounds us'. For example, if one reads prison graffiti (as one would read a poem more deeply), it may represent the cultural 'wounds' of the penal system as it appears on material structures. An analytical shift, from reading texts that are 'literary' to reading texts that more 'literally' represent transgression, may be a meaningful way to read the words that wound 'us' - words that work to deface/disrupt/destroy the material presence of white institutions. Prison graffiti, for example, captures the real-life emotional wounds of Others - it is textual reminder of a person's incarceration and could be a message of 
resistance to punitive punishment. Thus, how might reading prison graffiti from inside Don Dale Detention Centre invoke an emotive response that incites activism like any type of activist poetry can? Does prison writing inform debates about prison abolishment or offer new paradigms for radical changes to the penal system?

The over-representation of Aboriginal people in prison sees the penal system not only as a place of punishment but also as a means of cultural erasure. In the Northern Territory, for example, 94 per cent of inmates identify as Aboriginal and are more likely to return to prison within two years. ${ }^{7}$ The stark over-representation of Aboriginal people in prison is systemic to Australia's origins as a convict settlement, and this has been manifested as the criminalisation of blackness through the justice system. Aboriginal people have become disenfranchised and dispossessed through recurring periods of time in prison, away from their country, and from cultural participation. In "Settler colonialism and the elimination of the native," ${ }^{8}$ Patrick Wolfe argues that prisons operate through systemic structures of erasure, and are not dissimilar to the colonial designs of boarding schools and foster homes. He outlines how these institutions operate to privilege white society by keeping Aboriginal people away from home - devoid of sovereignty and alienated from native citizenship. Graffiti often functions in a cycle of appearance and disappearance in these very institutions; those in power methodically work to erase the graffiti of the oppressed in order to police how, where, and what a person writes, and to ensure messages are never communicated or received. As a transgressive art form, graffiti is therefore under constant threat of erasure. Before the opening of Darwin's Fannie Bay Gaol as a tourist site for example, the administrative board made to remove the graffiti from inside the prison ostensibly due to "careful consideration of inmates' privacy concerns'. ${ }^{9}$ The deliberate white-washing of such graffiti excludes Aboriginal voices from the cultural memory of being imprisoned in Darwin. Yet paradoxically, this is due to the fact they were incarcerated. According to criminologists Mark Halsey and Alison Young, ${ }^{10}$ it is highly unlikely that graffiti ever survives in prisons because authorities are quick to respond to it as something that is

.... out of place, which must be erased in order to return the social space to its proper condition.

Removal is thus a way of reappropriating the space, both taking back the space from the graffiti writer, and returning the space to a condition of propriety.

The focus on graffiti as a permeable text points to the ways it operates as both a discourse of erasure and as a discourse at risk of being erased. Since the 1970s, graffiti has been considered the illegal act of vandalism and was first outlawed in New York City. ${ }^{11}$ Banning graffiti however has only contributed to it becoming an emblem of activism all over the world, and graffiti can still be found in activist places like the Casma Valley in Peru, Nevada's Peace Camp, and the prison walls of Alcatraz. For example, on November 20, 1969, a group of First Nations People formed the Indians of All Tribes organisation and together occupied the abandoned prison on Alcatraz Island in San Francisco Bay claiming that abandoned federal land should be returned to American Indians. ${ }^{12}$ Over the course of two years, hundreds of Indians travelled back and forth to Alcatraz, leaving pro-Indigenous messages all over the walls of historic buildings on the island, such as "Peace and freedom welcome home of the free Indian land." ${ }^{13}$ Textual artefacts are those that can be read, not only as acts of transgression, but as writing that belongs to a genre functioning in complex and multilayered forms of activist writing. Other campaigns that have left textual remnants in the history of graffiti and activism include conflict graffiti from Egypt during the Tahir Square uprisings that read: "no to military rule;" ${ }^{14}$ Marxist propaganda found on the streets of Portugal; ${ }^{15}$ and expressions of gender inequality in Canada that states "think critically or die trying." 16 
There is a comprehensive history of graffiti across the world, yet graffiti as a written form is marginalised from textual analysis due to its 'illegitimacy' as an authored and published text. The themes of graffiti have not found common place in higher education classrooms and the absence of graffiti as set 'texts' in literary programmes has not enabled the potential power of graffiti to operate as activist writing in the same way that poetry and prose are studied. However, like graffiti on the walls of Alcatraz, transgressive text is an important act of reclaiming First Nation sovereignty as it works to more literally (and even literarily) to deface colonial institutions where white-stream policies are warehoused and protected. To reiterate Wolfe's enquiry into the culture of erasure, graffiti is important because it draws attention to public buildings that materially represent institutions responsible for colonial systems.

Literary studies may seem an incongruent place to engage with institutional matters of law and order, since Western universities also belong to an institution rooted in Western history and culture. Literary studies, for example, came about in the nineteenth century to service national imperialism and work for the empire to standardize the national language through particular rules of language and dialectology. ${ }^{17}$ With the empirical standardization of language and what should be considered 'literary', Western knowledge along with nationalist ideology became discursively stone-proofed by purists of the English canon. During the twentieth century however, the postcolonising and decolonizing of literary studies began through the work of many theorists such as Gayatri Spivak and Edward Said ${ }^{18}$. However, theoretical frameworks are yet again moving, and this time it is away from post-colonial theorising to instead delineate ideological discourses pertaining to what has been termed a decolonial turn - an intellectual movement concerned with the more practical implications of 'turning' the world into something, not just ideologically, but materially new. According to Vorster and Quinn, ${ }^{19}$ the decolonial turn began when student protests in 2015 and 2016 in South Africa saw the discourse of transformation becoming inadequate for academics wanting to see 'real change' to the decolonisation of knowledge and power. A cluster of discourses describe a decolonial turn that would in discourse and practical measures overturn the structures of colonial systems, and the institutions that house them including universities, court houses, and prisons.

Academics working in the discipline of literary studies are, too, being urged to reflect on how scholarship will untangle the colonial roots from which they work in order to change the lives of people in everyday life. In her article 'Resisting the institution', Aboriginal author and activist Evelyn Araluen argues that "literary and poetic theory" is guilty for being "elitist, ahistorical, esoteric and universalising" because it is a discipline that stems from the West. ${ }^{20}$ She insists that "Dialogues concerning the boundaries and possibilities of decolonisation ... demand political counterpoints," ${ }^{21}$ and poetical responses can become activist when used in activist places. ${ }^{22}$ Dylan Voller's sister Kira, for instance, reads her poetry across Australia to rally support for the end to youth incarceration. Similarly, a poem by acclaimed Wemba-Wemba and Gunditjmara writer, Paola Balla was published on Facebook before being cited in Westerly and is another example of how poetics can inspire activism at a national level in places other than books. ${ }^{23}$ Many people concerned about youth in detention posted photos from rallies on social media, displaying poetical responses on placards that read: Justice where the bloody hell are ya? And STOP Stealing Our Kids. Mainstream newsfeeds attracted varying comments on the Four Corners' exposé and the collage below represents differing views appearing online: 
He might not be a saint, but he is still a victim

Who do you blame for toy soldiers??

The boys?

Or those that turned them into soldiers?

Not all parents are up to the job, but if you're going to take that job away, you have to do it better.

It is difficult to find the right words to articulate the psychological and physical abuse of Aboriginal youth in Don Dale Detention Centre, and when Yolnu radio station reported the story at the time, the newsreader became stuck because there is no word for torture in the Yolnu language. ${ }^{24}$

The challenge for literary scholars (whose work is always a process of thinking and feeling) is to consider how the analysis of poetry and prose may contribute to real change to Australia's social and political worlds in the age of the decolonial turn. Arguably, exploring poetical responses to campaigns like Black Lives Matter is imperative to the success of such a campaign because scholars can articulate and intellectualise ideas through the exploration of imaginary worlds to create visions of new futures. The work of academics includes advocacy through classroom education, presenting at public events, and publishing scholarship that is accessible to a range of people from various fields and backgrounds (not just those belonging to the academy).

Graffiti is a transgressive textual form that has attracted considerable scholarly attention in visual arts, however to date, much work needs to be done to narrow the analytical lacuna in literary studies. In the 1970s, graffiti was first appreciated as a nascent art form for its contrasting colours, bold contours and impertinent styles. Artist and critic Brassai, for example, worked for over thirty years to capture, critique and preserve graffiti from the streets of Paris. ${ }^{25}$ He could appreciate how the drawings were calling him to understand the artists' purposes and meaning - feeling the artists' urgency to communicate with him, saying 'Save me, take me with you for tomorrow I'm no longer here. ${ }^{26}$ Graffiti as a study of typology and inscription is of increasing interest to academics, cultural theorists and public policy experts but literature that problematises its workings as an act of dialogue and poetic activism is rare. ${ }^{27}$

To date, Australian author and academic, Nicolas Rothwell, has contributed preliminary work to examine how graffiti in remote communities in the Northern Territory is a vernacular of the Aboriginal domain. Words and drawings are commonly found all over remote Aboriginal communities, and often walls, wheelchairs, baby cots and church louvres are scrawled with messages in distinct ways. In 'The Writing's on the Wall', Rothwell notes how graffiti from across the Northern Territory shares 'the same vocabulary' and that the authors are often young community people, dealing with romance, social status and the psychological troubles of their maker. Graffiti, he writes, has the potential to reveal more than a hundred government reports about remote community life as "words and slogans seek to testify, what their writers want is to be read, seen, noticed: to communicate with each other, in code, but a code so transparent it only heightens the message." 28

Before colonial invasion, the Aboriginal domain of text did not appear on walls, paper or papyrus, but on the permanent grounds of the earth. Rock art was textual in the form of marking the walls of 
caves with symbols, signs, codes and images pressed in ochre to trace the borders of the country, to tell ancient stories, as well as record the modern history of colonial invasion. Malarrak for instance is a site of rock art in Arnhem Land that captures European arrivals to Australia by boat, and records the first Aboriginal history of Australia's invasion. ${ }^{29}$ These visual etchings are made textual by narrating the changing nature of country, and embedding cultural memories within the permanent physicality of place.

The writing and marking on walls today can be seen as the continued resistance to the empirical practice of publishing only in the Western form of books - a practice synonymous with the settler's culture and domination since the birth of literary studies in empirical times. In Writing Never Arrives Naked, Penny van Toorn ${ }^{30}$ argues that books have operated historically as part of an empirical symbol of power - used to measure those without books as less civilized and without culture. She broadens the definitions of writing to include important cultural practices of scratching, cutting, carving, stamping, painting or scoring on surfaces that are not always in the form of a book or on paper. Capacious definitions of what constitutes 'writing' conflict with the empirical understandings of what is 'literary', and thus transgressive texts realise the 'literal' functions of protest writing. In this sense, reading rock art is to acknowledge First Nation sovereignty when custodians of the land recorded who they were and their witness of colonial invasion upon first point of contact. As an extension of this witness and resistance to colonial occupation, graffiti records the ongoing struggle for sovereignty across the country as it appears on statues, trains, concrete drains and official buildings that house their invaders' systems of control. The intrusive nature of colonial statues in public spaces is symbolic of the settler's invasion, while the palimpsestic nature of graffiti sprayed upon these statues is reminder of the illegitimate occupation of the colonisers in an uninvited space. For example, Matt Chun reflecting on the graffiti on western Sydney's Macquarie monument, notes how a memorial to the legacy of Lachlan Macquarie [fifth Governor of New South Wales] is itself an act of graffiti writ large, and writes: "monuments are the glib and artless "tags" of colonialism, imposed upon the unceded territories and existing histories of Aboriginal nations." 31

Since the invasion, Aboriginal people have had to communicate in distinct forms and media to bear witness to the ongoing violence and oppression afflicted upon them. It has become necessary to protect anticolonial attitudes from erasure in whatever ways possible, even in the face of dangerous situations where one could be punished for communicating messages of cultural rebellion. In contemporary literature for example, Birch uses graffiti inter-textually to symbolise protest and resistance against white police control. In his short story 'Colours', he makes visible the institutional abuse police use against Aboriginal people in police stations through the reflections of a teenage boy who is aware of his 'Pop's' enduring abuse from police. He writes: 'Police in our town were as crazy as any drunk and nobody expected better from them. Pop knew as much as was always telling me, You see the Gunjis coming, you run like hell. And I did. ${ }^{32}$ When the boy sees a police car making a U-turn, he tells himself to run as fast as he can in the other direction. The police officer catches up with him and says, "Looks like you're running from trouble...I'm talking to you, you half-caste cunt." The policeman grabs the boy by the throat and takes him back to the station to be taught "a lesson". It is not understood what the lesson is, but the police officer behind the desk at the station can decipher the boy's crimes by the infliction of his visible wounds - he sees he has "blood on his face and alcohol stains on his shirt" (although it is clear to the reader that the boy has not been drinking alcohol). 
The boy is thrown into a prison cell with a rubber mattress on the floor, and a toilet in the corner. There are no windows offering the boy connection with the outside world, so he begins reading messages from former inmates: "scribbled on the walls, some written in shit, marking who'd been there before me and which copper was a NO GOOD DOG." ${ }^{33}$ In fear he is going to be bashed by police, the boy quickly takes some paper from his pocket and rolls it up into tiny spit-balls, before adding it to the wall of graffiti to mark a constellation of stars from his grandfather's story. Once the paper is in place, he presses his whole body to the wall and thinks to himself: "my stars were dancing, where my story was waiting to be told." 34

The police officers suddenly enter the cell to find that the boy has "vanished". The boy has found "a way to be with himself" 35 and not at the mercy of his racist abusers. In essence, the boy's metaphysical disappearance is an abrupt reminder that Aboriginal boys are at grave risk of dying in custody. In regards to Wolfe's ${ }^{36}$ arguments concerning the elimination of the native, institutions such as prisons remove Aboriginal people from their land and from their families, to not only erase an Aboriginal presence from society, but to make their connections to sovereignty invisible as well. In an act of resistance therefore, the boy puts his ancestral story on the wall of his cell to relinquish his identity as an Aboriginal person within an invisible space.

Birch's writing goes well beyond the visibly etched material text - it is symbolic of struggles characteristic of what Brighenti Mubi ${ }^{37}$ terms the 'field of visibility' - which is the important right to see and to be seen. Visibility is essential to transgression and remains an everlasting source of symbolic conflict between settlers and First Nation peoples. The wall of the cell is used not only for communication but for visibility through an act of anti-citizenship. In a twist to Birch's plot however, the boy makes tactical use of space within the field of visibility by becoming invisible to his oppressors. According to Michel de Certeau, ${ }^{38}$ the oppressed will deliberately carry out acts of civil warfare because there exists the common citizen's creative ability to resist hegemonic logics and the domain of more powerful social actors. He writes:

Many everyday practices...are tactical in character. And so are more generally, many ways of operating: victories of the weak over the strong' whether the strength be that of powerful people or the violence of things or of an imposed order; clever tricks, knowing how to get away with things, 'hunters cunning', manoeuvres, polymorphic simulations, joyful discoveries, poetic as well as warlike. ${ }^{39}$

Graffiti operates as the case in point, occupying a space of visibility in a colonial world of strict surveillance and oppression. Disappearance is the implicit motif of Birch's prison story 'Colours', pointing to the very reasons why incarceration should be abolished and made to disappear. The story implies that the alternate model to punitive punishment is to address social problems such as structural racism exercised by police so that Aboriginal people are no longer vulnerable to threats of cultural erasure.

Similarly, Birch's novel Blood uses inter-textual graffiti to emphasize interracial conflict between Aboriginal people and white police officers. The first page of the novel begins with the vivid image of graffiti etched into a wooden table at a police station. A police woman walks into the interview room carrying a tray of food for Jesse, a young boy being held in custody. She puts the tray of food 
down on the wooden table where it has been scratched - Fuk the cops. ${ }^{40}$ Jesse however imagines the wooden tabletop reads J and R: "Jesse and Rachel" "Jesse and Rachel Were Here". ${ }^{41}$ The graffiti foreshadows the relationship Jesse has with his sister Rachel from the very beginning. Much like the graffiti Rothwell observes in remote Northern Territory communities, Birch uses intertextual graffiti to portray not only where characters have been, but in proximity with whom, and how their relationships (both familial and those of hostility with police) have wider implications for belonging and cultural survival. Jesse's reimagining of the graffiti text implies that the antithesis of police control is of course to be with one's family. The graffiti that is not imagined by Jesse but actually appears on the table - Fuk the cops - reflects the aggressive relationship that police have with detainees in the context of incarceration. The tensions captured here, and in Birch's aforementioned short story 'Colours', are unfortunately representative of the material world and the real plight for Aboriginal people commonly facing police harassment and abuse in prisons. The Four Corners' programme 'Australia's Shame' showed children as young as twelve years old for example, being physically and psychologically abused by prison guards on a regular basis. One of the children featured in this news programme was Aboriginal boy, Dylan Voller and CCTV footage shows three prison guards entering Voller's cell, stripping him naked and physically manhandling him face down on a mattress on the floor. The programme reports that Voller was subject to indefinite time in isolation without access to basic human rights as a child. Despite being suicidal, Voller was not offered access to appropriate services but instead blindfolded with a spit-hood and put in a restraint chair 'for his protection'. Voller's experience is not idiosyncratic to the Northern Territory and others, such as Thomas Hickey of Redfern, Palm Island man Mulrunji Doomadgee, and Western Australian woman Ms Dhu, have been subjected to police violence and died under the watch of police. Birch reports spending time interviewing police during the Thomas Hickey investigation, and through his own creative writing on such themes, ensures these real stories will always remain in the news.

In an interview published in Overland, ${ }^{42}$ Birch reflects on the complexity of knowing how to speak within institutions that are built on racial power structures and notes how the behavior of police changes when speaking about Aboriginal people in public and in private. In relation to Thomas Hickey, he said:

I found some of the media coverage of that really horrific in regard to the demonization of young Aboriginal people but also even in the critique of that. I still find the most saddened and poignant outcome of that, is that he actually died in the arms of a policeman, and they interviewed that policeman, and the way that policeman spoke indicated something very different than you might expect in the sense that at an individual humanistic level, that policeman felt great sadness for what had happened but once you put that into an institutional context that narrative has no place, so it was never mentioned again...but it's one of those things that state power and the way that we act when we're inside institutions often strips us of our own humanity or that potential... I'm really interested in the way that institutions function to disempower people but also to strip people within those institutions of their capacity to engage with others in the more humane way.

In this same interview Birch shares how his close friend died in prison and that this trauma still continues to deeply affect him. This trauma is captured in his poem 'Michael' in Broken Teeth, ${ }^{42} 3$ where he alludes his friend's death may have occurred in the Pentridge Gaol in Melbourne. 
A stanza from his poem reads:

I see your face baby smiling

innocent into the camera's eye

shooting you

and taking the bread board

in my hand

(sent home from Pentridge)

I finger deep scars

The atrocities that occurred within Darwin's Don Dale Detention Centre continue to affect the Northern Territory community deeply and protests for prison abolishment is a sign that many are still fingering the deep scars. In the context of wanting to understand deeply, one may see Dylan Voller's prison graffiti as a type of textual scarring that is evidence of his unjust abuse by prison staff. Dylan's markings, like those of the boys in Birch's stories, exist within the invisible space of the prison and wound us with the shame of long-term collective memory.

The Royal Commission's enquiry into the protection of children in the Northern Territory found in 2017, that Dylan Voller spent too many days of his young life locked in an isolation cell where he was subject to incessant heat, filth and not knowing how long he would be in isolation. Footage from the Four Corners' programme show Dylan carving his name into the concrete walls of his cell BMU1 and viewers bear witness to a boy who is clearly distressed. His graffiti is captured from a freeze-frame on the cell's wall and reads:

Dv

\section{D.VOLLER}

\section{DyIAN}


According to psychologists 'the signature effect' examines how one signs their name in particular situations of stress. The psychological theory claims that the size of a person's signature is linked to their self-esteem and the regulation of one's negative emotions caused by threats to self-worth. According to Frijda ${ }^{44}$ for example, initialling over and over again is a defense mechanism one uses when they are suffering from chronic anxiety and despair.

In relation to Birch's story 'Colours', one could liken the act of graffiti-ing as a creative maneuver to 'be with himself' and to capture his identity in an invisible space. To read graffiti like a poem means seeing more than a signature or ludic scribble but rather an activist's writing appearing in an activist place. What was once his prison wall for example, is now a space for dialectics to be understood and responded to. Dylan has gained 'authority' to speak because his graffiti tests authority, it disrupts the construct(ion) of the prison system through the production of transgressive text upon its very walls. The inscription of only three words on a wall becomes part of the larger production of activist writing belonging to prisons all over the world, including Alcatraz which now stands as a monument of freedom and sovereignty writ large. For protestors wanting prison abolition in the Northern Territory, there may be possibilities for reclaiming Don Dale Detention Centre (in the same way as Alcatraz) to reform it as a place of freedom, if not adequate rehabilitation.

Like the script carved on the prisoner's back in Kafka's story, Dylan's name crosses space and time, leaving not only a wall, but many of us (as witness) permanently marked. Wounds of the skin have represented the colonial pursuit to criminalise blackness, and Kafka's story makes readers think about the implications of seeing such markings to awaken typographical silence. If one reads graffiti more deeply how might words of graffiti tremble as they are put into discourse? We may hear an utterance of lament - a message from the author's self-conscious that informs the urgent need for a decolonial turn.

Like a poem, all three lines of Dylan's name work to disrupt habitual aspects of language as it appears on a wall, yet call us towards who he is - his subjectivity - and what he has been subject to. His name appears like a stream of consciousness, yet there is structure and rhythm to the text - the first line for example reads as two syllables, then the second line with three, then end with two syllables again. His writing exhibits architectural absence because it lacks predictable form: there are no verses or stanzas like a typical poem. The punctuation is limited, and a mixture of capitalized letters implies fractured text that has been put together to point to a fractured mind as a result of institutional abuse. Or conversely, it could be text deliberately deranged for harder impact on the (mind's) eye. The narration (or lack thereof) is non-linear and devoid of textual resolution. Yet the poem is not without outline - as readers we can make sense of a hidden presence, margins of silence, and how a 'white' space can be framed on a concrete wall. The context provided by the Four Corners' programme makes the poem's linguistics audible and Dylan's name is rarefied as it reaches an intense public stare. Reading his work as 'poetry' thus illuminates inter-textual meanings that are powerful because the writing is everything that it should not be: non-literary, unconventional, atypical, anti-canonical and anti-textual. The poem defies many notions of what we consider 'literary' and who might be considered an author since Dylan is not given authority to speak. It is the poem's precise position as an anti-text however, that gives it rise to writing belonging to the oppressed, appearing in new and unearthed forms. Graffiti as polemical discourse does not fit neatly within the master-narratives constituting the literary realm, instead creating an abyss to be further explored as dialectics of the decolonial turn. 
A theoretical interpretation of 'graffiti poets' also asks us to defy fundamental concepts underpinning literary theory and who is an author. Roland Barthes' 'The Death of the Author' 45 for example, is a theoretical framework that cannot be applied to graffiti poetry written in prisons and published on walls. In his essays 'The Death of the Author' and 'From Work to Text', Barthes argues that an author is necessarily reduced to a material object and that the biographical context of an author is irrelevant because it only detracts from a more revelatory reading of a text. On the other hand, Foucault's theoretical expositions of 'What is an author' argues that a text does not imply an author at all and that a text could be simply anything written or printed. ${ }^{46}$ Foucault asks himself, and of his intellectual opponent Barthes, "If an individual is not an author, what are we to make of those things he has written or said, left among his papers or communicated to others?" 47 During the to-ing and fro-ing of their correspondence, Barthes insists "Writing is the destruction of every voice, of every point of origin. Writing is that neutral, composite, oblique space where our subject slips away. .." 48 Yet as a matter of life and death, the opposite must be true when analyzing graffiti in prisons. For when readers separate what (was written) from who (has written it), it does not allow for the insight needed to support prison transformation or abolishment. Graffiti poems thus disrupt Barthes and Foucault's literary theories, creating an equivoque on the death of the author to insist that we read graffiti with hope that the author does not slip away - that the author does not die in custody. This wanting to know the circumstances of a graffiti writer is necessary to uncover those messages being kept secret, disappearing, and made forgotten in Australia's prison narratives.

Yet like any page of a book, a concrete wall operates as an interface for reading and writing, and words are encountered as transgressed bodies and texts. Prison walls are a space where profanity and poetics morph to create a dialectics calling to be read and responded to like any other form of writing. Textual artefacts, like graffiti, may assume to lack artistic design but can, through this lacking, help a reader to locate poetic entrails rather than solely poetic functions. If graffiti is examined as a socially embedded act like writing for example, the reader is invited to engage in a dialogue that may also be political. ${ }^{49}$ By reading the assault that graffiti has on civic constructions, we may become open to its poetic workings, the stirring of empathy and even be moved towards activism that guides the decolonial turn. Without response, we are at risk of becoming the traveller in Kafka's story who lives in a state of ignorance denying (the island's) structural reform.

The act of reading Dylan's name over and over again as he carves his initials into a cell wall, calls viewers of the Four Corners' programme to read not only the treatment of Others, but to reflect deeply on Australia as a nation with many emotional and spatial distances between us. As Montagu ${ }^{50}$ writes in Touching the human significance of the skin, "It is feeling that bridges the spatial gap that separates us from others, and puts us in touch with them." The Four Corners' programme has provided viewers with a virtual space in which the conditions of bodies can 'impress' upon us the wounds of a penal colony. Viewers are given permission to see and therefore to feel with empathy. Similarly, Ahmed ${ }^{51}$ argues that "emotions become attributes of collectives" and that the "national character (what the nation is like) is a direct result of how bodies move away or towards other bodies in culture." Hence, the practice of imprisonment should be abolished because it not only enforces the elimination of the native, but is a system that prohibits meaningful race relations as well; while bodies are in isolation, they cannot press upon each other in a field of visibility. 
This essay has experimented with the profound ways that graffiti 'poetically' tests how we read colonial violence in Australia's youth prison systems. Graffiti acts as sharp textual artefact that carves meaning upon civil constructions, leaving them, and us, permanently marked. The effect of such poetry wounds us when, as readers, we realize the real conditions where vulnerable people must write. Graffiti all over the world speaks to a colonized world that is still learning how to 'read', and how to 'speak' in response. And perhaps there are times that require no talking at all. Timmah Ball ${ }^{52}$ for example writes how frustrating it is when "white people always have the final say." In spirit of Ball's argument, this essay closes with two poems written by Dylan Voller informing a poetics of justice. The first poem is published online by Honi Soit and is entitled, 'Justice for Youth' ${ }^{53}$ :

When I close my eyes I feel the hits to my head. But don't get me started on all the abuse and torment.

I was only eleven years I didn't know If It was Right or Wrong. But what I know now is theese Assaults went on for way to Long.

Sitting in that chair with a hood over my head. For the whole two and a half hours I was Just wishing I was Dead.

I remember that time [name removed] told me to kill myself. I thought about it for days If only you could feel the pain I felt.

I'm not gonna lie theres been times I have cried. And thought to myself am I gonna die in side.

I have a lot of questions I really want answered. Like why wern't my first cry's out for help ever answered.

Does [name removed] Really not care. Or is [they] telling the truth and [they] didn't know what was going on in there.

Why can't [name removed] Admit [they] was wrong. Instead of pointing fingers and passing the Blame Along.

The second poem reads on a concrete wall: ${ }^{54}$

Dv

D.VOLLER

DyIAN

Dr Adelle Sefton-Rowston is a Lecturer in Communications and Coordinator Bachelor of Arts at the College of Indigenous Futures, Arts and Society, Charles Darwin University, Darwin, Northern Territory, Australia. 
1. Franz Kafka, "In the Penal Colony," in The Metamorphosis and Other Stories (Oxford: Oxford University Press, 2009), 77.

2. Kafta, "In the Penal Colony," 78.

3. Franz Kafta, Letters to Friends, Family and Editors, trans. Richard and Clara Winston (New York: Schoeken Books, 1977).

4. Kim Scott, Taboo (Sydney: Pan Macmillan, 2017).

5. Paul Collis, Dancing Home (St Lucia: University of Queensland Press, 2017).

6. Tony Birch, Common People (St Lucia: University of Queensland Press, 2017).

7. Northern Territory Government, Northern Territory Department of Correctional Services Annual Statistics 2014 - $2015 \quad$ (2016) https://justice.nt.gov.au/__data/assets/pdf_ file/0009/269793/2014-15-NTDCS-AnnualStatistics.pdf (accessed 23 January 2018).

8. Patrick Wolfe, "Settler colonialism and the elimination of the native," Journal of Genocide Research 8:4 (2006), 387-409.

9. Jacqueline Z. Wilson, Prison: Cultural Memory and Dark Tourism (New York: Peter Lang Publishing, 2008), 68.

10. Mark Halsey, and Alison Young, "The Meanings of Graffiti and Municipal Administration," Australian and New Zealand Journal of Criminology, 35:2 (2002), 175.

11. Troy Lovata, and Elizabeth Olton, eds., Understanding Graffiti: Multidisciplinary Studies from Prehistory to the Present (California: Left Coast Press, 2015), 11-19.

12. Troy Johnson, and Donald Fixico, The American Indian Occupation of Alcatraz Island: Red Power and Self-Determination (Lincoln: University of Nebraska Press, 2008).

13. Carl Nolte, "Alcatraz pays tribute to Indian occupation," SFGATE, 14 January 2013, 1. www. sfgate.com/bayarea/article/Alcatraz-pays-tributeto-Indian-occupation-4191169.php

14. Jeffrey lan Ross, ed., Routledge Handbook of Graffiti and Street Art (London: Routledge, 2016), 320.

15. Ross, Routledge Handbook of Graffiti, 302.

16. Ross, Routledge Handbook of Graffiti, 85.

17. Margery Fee, "Writing orality: Interpreting literature in English by aboriginal writers in North America, Australia and New Zealand," Journal of Intercultural Studies, 18:1 (1997), 27.

18. Gayatri Chakravorty Spivak, "Scattered Speculations on the Question of Value." In Other Worlds: Essays in Cultural Politics (New York: Methuen 1987). Edward Said, Joseph Conrad and the Fiction of Autobiography (New York: Columbia University, 2008).
19. Jo-Anne Vorster, and Lynn Quinn, "The 'Decolonial Turn': What does it mean for academic staff development?" Education as Change 21:3 (2017), 31-49.

20. Evelyn Araluen, "Resisting the institution," Overland, 227: Winter (2017), 7.

21. Araluen, "Resisting the institution," 6.

22. Araluen, "Resisting the institution," 9.

23. Paola Balla in Timmah Ball, "In Australia White people write my culture for me," Westerly, 61:2 (2016), 35.

24. Amy Thomas, "It is still the Balanda way," Overland, 226, Autumn (2017). https://overland.org.au/ previous-issues/issue-226/essay-amy-thomas/

25. Robert Reisner, Graffiti: Two Thousand Years of Wall Writing (Chicago: Henry Regnery Company, 1971), 96.

26. Reisner, Graffiti, 96.

27. Lovata and Olton, Understanding Graffiti, 11-19.

28. Nicolas Rothwell, "The writing's on the wall," The Australian, 19 January 2013. http://www.theaustralian.com.au/arts/ review/the-writings-on-the-wall/news-story/ edb92d36c879d56320ff7722e96a3a72 .

29. James Woodford, "The rock art that redraws our history," The Sydney Morning Herald, 20 September 2008, http://www.smh.com.au/ news/national/rock-art-redraws-our-histo ry/2008/09/19/1221331206960.html

30. Penny van Toorn, Writing Never Arrives Naked: Early Aboriginal cultures of writing in Australia, (Canberra: Aboriginal Studies Press, 2006).

31. Matt Chun, "National Accounts," Meanjin Quarterly, 76:3 (2017), 3.

32. Tony Birch, "Colours," in Common People (St Lucia: University of Queensland Press, 2017), 195.

33. Birch, "Colours," 201.

34. Birch, "Colours," 202.

35. Birch, "Colours," 202.

36. Wolfe, "Settler colonialism," 387-409.

37. Andrea Brighenti Mubi, "At the Wall: Graffiti Writers, Urban Territorality, and the Public Domain," Space and Culture, 13:3 (2010), 315-332.

38. Michel de Certeau, The Practice of Everyday Life (Berkeley: University of California Press, 1980).

39. de Certeau, The Practice of Everyday Life, xix.

40. Tony Birch, Blood (St Lucia: University of Queensland Press, 2011), 1.

41. Birch, Blood, 3.

42. Adelle Sefton-Rowston, “You'll be great, but only if you work your arse off. An interview with Tony Birch," Overland (Online), 28 March 2017, https:// overland.org.au/2017/03/youll-be-great-but-onlyif-you-work-your-arse-off-an-interview-with-tonybirch/ 
43. Tony Birch, “Michael," in Broken Teeth (Melbourne: Cordite Books, 2016), 67.

44. Nico H. Frijda, "The Laws of Emotion," American Psychologist, 43:5 (1988), 349-358.

45. Roland Barthes, "The Death of the Author," in The Book History Reader, ed. David Finklestein and Alistair McCleery (Routledge: London, 2006), 277 80.

46. Barthes, "The Death of the Author," 277.

47. Sean McQueen, "Michel Foucault's "What is an Author?" and Adaptation," Colloquy Text theory critique, 24 (2012), 60-77.

48. Adrian Wilson, "Foucault on the "Question of the Author": A Critical Exegesis," The Modern Language Review, 99:2, (2004), 339-363.

49. Barthes, "The Death of the Author," 218-19.
50. Jennifer Baird, and Claire Taylor, eds. Ancient Graffiti in Context (New York: Routledge, 2010).

51. Ashley Montagu, Touching the human significance of the skin (New York: Harper and Row, 1986), 125.

52. Sara Ahmed, The cultural politics of emotion (Edinburgh: Edinburgh University Press, 2014), 130.

53. Timmah Ball, "In Australia White people write my culture for me," Westerly, 61:2 (2016), 35.

54. Dylan Voller, "Justice for Youth: Original Poetry by Dylan Voller," Honi Soit, 26 January 2017, http:// honisoit.com/2017/01/justice-for-youth-originalpoetry-by-dylan-voller/ 
